\title{
Surface Barriers of Mandarin 'Okitsu' Leaves Make a Major Contribution to Canker Disease Resistance
}

\author{
María A. Favaro, Norma G. Micheloud, Roxana A. Roeschlin, María A. Chiesa, Atilio P. Castagnaro, Adrián A. Vojnov, \\ Fred G. Gmitter, Jr., José Gadea, Luis M. Rista, Norberto F. Gariglio, and María R. Marano
}

First, third, fourth, and eleventh authors: Instituto de Biología Molecular y Celular de Rosario (IBR)-Consejo Nacional de Investigaciones Científicas y Tecnológicas (CONICET), Área Virología, Facultad de Ciencias Bioquímicas y Farmacéuticas, Universidad Nacional de Rosario (UNR), Ocampo y Esmeralda, S2000FHN Rosario, Argentina; first, second, ninth, and tenth authors: Facultad de Ciencias Agrarias, Universidad Nacional del Litoral (FCA-UNL), Depto. de Producción Vegetal, Kreder 2805, S3080HOF Esperanza, Argentina; fifth author: Instituto de Tecnología Agroindustrial del Noroeste Argentino (ITA-NOA), Estación Experimental Agroindustrial Obispo Colombres (EEAOC)-CONICET, Av. William Cross 3150, Las Talitas, T4101XAC Tucumán, Argentina; sixth author: Instituto de Ciencia y Tecnología Dr. Cesar Milstein, Fundación Pablo Cassará-CONICET, Saladillo 2468, C1440FFX Ciudad de Buenos Aires, Argentina; seventh author: Citrus Research and Education Center (CREC), University of Florida, 700 Experiment Station Rd., Lake Alfred 33850; and eighth author: Instituto de Biología Molecular y Celular de Plantas (IBMCP), Universidad Politécnica de Valencia-C.S.I.C, Ingeniero Fausto Elio, s/n, 46022 Valencia, España.

Accepted for publication 10 February 2014.

\begin{abstract}
Favaro, M. A., Micheloud, N. G., Roeschlin, R. A., Chiesa, M. A., Castagnaro, A. P., Vojnov, A. A., Gmitter, F. G., Jr., Gadea, J., Rista, L. M., Gariglio, N. F., and Marano, M. R. 2014. Surface barriers of mandarin 'Okitsu' leaves make a major contribution to canker disease resistance. Phytopathology 104:970-976.
\end{abstract}

ABSTRACT

Field evaluations have shown that Satsuma mandarin (Citrus unshiu) 'Okitsu' is one of the mandarin cultivars that shows substantial resistance to Xanthomonas citri subsp. citri (X. citri), the causal agent of citrus bacterial canker disease. However, the mechanisms underlying this resistance are not well understood. In this study, we have shown that 'Okitsu' leaves are nevertheless susceptible to $X$. citri infection during a period of their development; however, this period is shorter than that seen in the susceptible mandarin 'Clemenules' $(C$. clementina). Under controlled growth conditions, the resistance of 'Okitsu' to $X$. citri was associated with the age of the leaf and was evident in spray-inoculated plants but not in those inoculated by infiltration. Furthermore, $X$. citri showed reduced attachment and biofilm formation in 'Okitsu' leaves compared with 'Clemenules'. Taken together, our data suggest that structural features of the 'Okitsu' leaf surface, such as the physical properties of the cuticle, are involved in the resistance to $X$. citri.

Additional keywords: canker resistance, leaf surface properties, phenological stages.
Citrus is the most economically significant fruit tree crop in the world, with an annual production of 87 million tons. Mandarin cultivars and their hybrids are the second most important Citrus sp. after orange (http://www.fas.usda.gov). In Argentina, the annual production of mandarin is approximately 555,000 tons (http://www.federcitrus.org), with Citrus clementina 'Clemenules' and $C$. unshiu 'Okitsu' as the main cultivars grown in this country (2). 'Clemenules', originated by spontaneous mutation of 'Clementine', dominates mandarin production due to its excellent organoleptic characteristics $(32,38)$. In Argentina, it is harvested from early May to June, and its fruit is seedless in the absence of crosspollination, which is well accepted in the world markets (31). 'Okitsu' has lower taste quality but it is the earliest citrus fruit produced in Argentina, satisfying the domestic demand for fresh citrus fruit in March, during a period of limited availability.

Argentina is among the first seven world exporters of fresh mandarin fruit, and one quarter of its production is sold to the

Corresponding authors: M. R. Marano; E-mail address: marano@ibr-conicet.gov.ar; and N. F. Gariglio; E-mail address: ngarigli@fca.unl.edu.ar

* The $e$-Xtra logo stands for "electronic extra" and indicates that Figures 4 and 5 appear in color online.

http://dx.doi.org/10.1094/PHYTO-10-13-0277-R

This article is in the public domain and not copyrightable. It may be freely reprinted with customary crediting of the source. The American Phytopathological Society, 2014 northern hemisphere (http://www.fas.usda.gov). The major threat for this citrus market is the possible imposition of quarantine restrictions as a consequence of citrus canker disease, caused by the bacterial phytopathogen Xanthomonas citri subsp. citri $(X$. citri). The attachment of $X$. citri to plant cell surfaces is essential for its pathogenesis. Bacteria grow and persist as epiphytes, forming biofilms on the host surface prior to endophytic colonization of the mesophyll tissue through natural openings, such as stomata, or through wounds $(21,33,40)$. A balance between biofilm formation and bacterial dispersion is necessary during disease progression and for survival of the pathogen (33).

Citrus plant leaves are highly susceptible to infection by $X$. citri during development, when they have reached 50 to $100 \%$ of their final size (20). Canker symptoms are characterized by surfacepenetrating necrotic lesions surrounded by oily, water-soaked margins and yellow chlorotic rings (21). Citrus canker can be a severe disease in geographic areas where rainfall and wind are frequent during periods of shoot emergence and early fruit development (7).

Argentina currently manages citrus canker through an integrated disease control program based on canker-free nursery stocks, windbreaks, pruning of infected twigs and periodic chemical control of the pathogen by spraying with copper-based bactericides (8). However, the utilization of resistant cultivars in the field is the most effective way to overcome the pathogen $(13,39)$.

Although most commercially important citrus cultivars are susceptible to $X$. citri, a wide range of citrus species and cultivars, 
as well as some related genera, are moderately to highly resistant to this pathogen $(10,12,13,19,24,26,34,35,39)$. Pathogenic and histo-anatomic assays suggest that plant preformed defenses, involving physical barriers such as cell wall and membrane ultrastructure, waxy cuticles, and the number and anatomy of the stomata, could be involved in resistance to bacterial invasion $(10,22,41)$. However, artificial inoculation through infiltration or pin prick (which bypasses the preformed defenses) on resistant 'Chinese' citron (C. medica) and 'Nagami' kumquat (Fortunella margarita) suggests that the specific recognition of a $X$. citri virulence effector could also occur in the plant $(12,23,24)$.

Among mandarin cultivars, 'Okitsu' was found to be more resistant to canker development than 'Clemenules' $(13,20,35,36)$, although the mechanisms causing this differential resistance are still unknown. In this work, we found that 'Okitsu' is susceptible to $X$. citri infection during leaf development but the period of susceptibility is shorter than for 'Clemenules'. Moreover, we demonstrated that resistance to $X$. citri in 'Okitsu' is only observed when bacterial inoculation is made by a noninvasive spraying method, as opposed to infiltration into the leaves. Our findings suggest that the properties of the leaf surface play a critical role in limiting bacterial epiphytic fitness and biofilm formation and, therefore, represent an important primary defense against pathogen colonization and subsequent disease development.

\section{MATERIALS AND METHODS}

Field assessment of citrus canker disease. The mandarin orchard analyzed in this study is located in the experimental field of the Universidad Nacional del Litoral, Esperanza, Santa Fe, Argentina ( $31^{\circ} 26^{\prime} \mathrm{S} ; 60^{\circ} 56^{\prime} \mathrm{W}$; $40 \mathrm{~m}$ above sea level). According to Köppen classification (25), the climate of this region is humid subtropical without a dry season. In this area, the temperatures averaged $11^{\circ} \mathrm{C}$ in winter and $25^{\circ} \mathrm{C}$ in summer. Annual rainfall is $938 \mathrm{~mm}$ and rain falls mostly during spring and early summer (between September and December). Storms and average wind speed increase from August to December (16). Field assessments were conducted on 10-year old 'Clemenules' ( $C$. clementina Hort. ex Tan.) and 'Okitsu' (C. unshiu Marc.) mandarin trees, grafted onto Poncirus trifoliata (L.) Raf. rootstocks. They were planted with 5.0-by-3.5-m spacing on a silt-loamy soil and subjected to drip irrigation. Fertilization, pruning, and pest management were made in accordance with normal commercial practices, including a natural windbreak barrier of $15 \mathrm{~m}$ in height surrounding the experimental field, forming squares of 1 ha (17). A complete random experimental design with single-tree plots and eight replications per cultivar was used. In spring 2009 and 2010, four young healthy branches per tree were randomly selected at $1.5 \mathrm{~m}$ of height from the four quadrants of the tree canopy. Phenological stages of the new shoots were recorded using the Biologische Bundesanstalt, Bundessortenamt and Chemical Industry (BBCH) scale for citrus, developed by Agustí et al. (1). Leaves from selected branches were monitored for canker disease in December, when symptoms were well developed. Disease incidence of citrus canker was expressed as percentage of leaves with canker symptoms over total leaves examined, according to Leite et al. (27). Estimation of citrus canker severity was evaluated in the five most infected leaves of each shoot of the four quadrants per tree, based on the four diagrammatic scales published by Belasque et al. (5). Symptoms were registered by digital photographs and the data were analyzed according to Student's $t$ test $(P<0.05)$. Confirmation of the cankerous lesions of infected mandarin trees was accomplished by bacterial isolation and molecular analysis (11).

Bacterial strains and pathogenicity assays of Xanthomonas spp. in growth chamber. $X$. citri strain $\mathrm{A}^{\mathrm{E} 28}$, isolated from an experimental field of the Universidad Nacional del Litoral, Argentina, was used in the inoculation assays under controlled conditions. X. fuscans subsp. aurantifolii strain C-1473 (X. aurantifolii $\mathrm{C}$ ) was provided by Dr. Canteros, Instituto Nacional de Tecnología Agropecuaria, Bella Vista, Corrientes, Argentina (11). Both Xanthomonas strains were transformed by electroporation with plasmid pMP2444 expressing the green fluorescent protein (GFP) (14).

One-year-old 'Clemenules' and 'Okitsu' plants, grafted onto $P$. trifoliata rootstock, were kept under controlled greenhouse conditions. New shoots approximately $1 \mathrm{~cm}$ long and with at least five leaves were selected after pruning the plants. All the leaves on these shoots were considered to be of the same ontological age (37). Bacterial suspensions were prepared in $10 \mathrm{mM} \mathrm{MgCl}_{2}$ solution and $X$. citri and $X$. aurantifolii $\mathrm{C}$ were inoculated on leaves of the new shoots. In order to properly quantify canker lesion production, a different inoculum concentration was used for each inoculation method: $10^{3} \mathrm{CFU} / \mathrm{ml}$ for pressure infiltration and $10^{7} \mathrm{CFU} / \mathrm{ml}$ for spraying $(33,37,39)$. A $10-\mathrm{mM} \mathrm{MgCl}_{2}$ solution was used as a negative control for inoculation. Inoculated plants were maintained for 40 days in a growth chamber, with temperatures of 25 to $28^{\circ} \mathrm{C}$, high humidity (>95\%), a 14-h photoperiod, and a light intensity of 150 to $200 \mu \mathrm{E} / \mathrm{s} / \mathrm{m}^{2}$. All plant inoculations involved a minimum of two shoots with at least five leaves from each plant and four plants for each mandarin cultivar. Disease progression was monitored phenotypically in three separate biological assays and the number of cankers per square centimeters was quantified 30 days postinoculation (dpi) using Image $\mathbf{J}$ software (v 1.41; National Institutes of Health, Bethesda, MD). Statistical analysis of data was performed using the Student's $t$ test $(P<0.05)$. Bacterial population in leaves from both mandarin cultivars was measured as previously described (33).

Bacterial attachment and biofilm formation assays. Bacterial adhesion and biofilm formation on abaxial surfaces of 'Clemenules' and 'Okitsu' leaves were analyzed by crystal violet staining, as previously reported (33). Stained bacteria attached to the leaf surface were examined and photographed under white light using a microscope (BX50F4; Olympus Optical Ltd. Company, Tokyo).

Epiphytic bacterial growth and biofilm formation on mandarin leaves were also examined using gfp-tagged $X$. citri cells (X. citriGFP), as described previously (33). 'Clemenules' and 'Okitsu' leaves were sprayed with a suspension of $X$. citri-GFP as described above. Bacterial growth and biofilm formation were monitored on the abaxial surface of approximately $1-\mathrm{cm}^{2}$ leaf samples using a fluorescence microscope (BX50F4; Olympus Optical Ltd. Company) or an inverted confocal laser-scanning microscope (C1 Eclipse TE-2000-E2; Nikon Instruments Inc., Melville, NY). Simulated three-dimensional images and sections were generated by the program Nikon EZ-C1 3.9 Free Viewer. Experiments were repeated twice on at least three different plants for each cultivar and three leaves per plant.

\section{RESULTS}

Resistance to canker disease in 'Okitsu' leaves is associated with a reduced period of high susceptibility to $X$. citri. The developmental period of maximum susceptibility to $X$. citri occurs between phenological stages BBCH 15 and BBCH 19 of Citrus spp. shoots, corresponding to leaves expanded to 50 to $100 \%$ of their final size, respectively $(1,20)$. These phenological stages were monitored in 'Clemenules' and 'Okitsu' plants grown in the experimental field between September and November 2009 and 2010. Notably, the period of time spent by 'Clemenules' shoots between BBCH15 and BBCH19 was 16 (in 2009) and 10 (in 2010) days longer than for 'Okitsu' shoots (Fig. 1A).

In order to associate these phenological data with canker lesions under field conditions, disease assessment was conducted on four selected branches from spring leaf flush of each tree in December of the two consecutive years. In 2009, canker average 
incidence in 'Clemenules' was 10-fold higher than in 'Okitsu'. The same trend was observed in 2010, although the difference between the cultivars was 11-fold (Fig. 1B). Average severity measurements showed the highest differences in canker lesion parameters between cultivars, with fold differences of 'Clemenules' over 'Okitsu' of 26.6 (in 2009) and 18 (in 2010). Finally, maximum severity was 4.7- and 2.8-fold higher in 'Clemenules' compared with 'Okitsu' over the same period of time (Fig. 1B). Taken together, these results confirm that 'Okitsu' is more resistant to $X$. citri infection than 'Clemenules' and suggest that the shorter length of the phenological period of susceptibility of 'Okitsu' shoots may be an important factor contributing to its greater resistance to canker disease under field conditions.

The resistance to canker disease is bypassed when the $X$. citri strain is inoculated by infiltration into 'Okitsu' leaves.

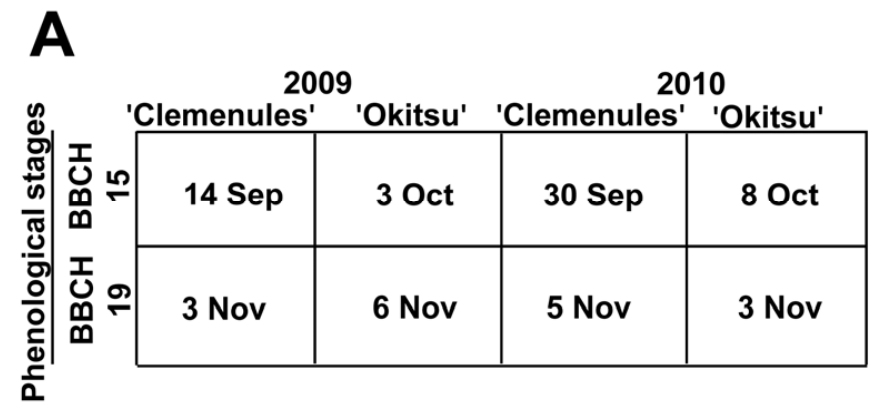

B

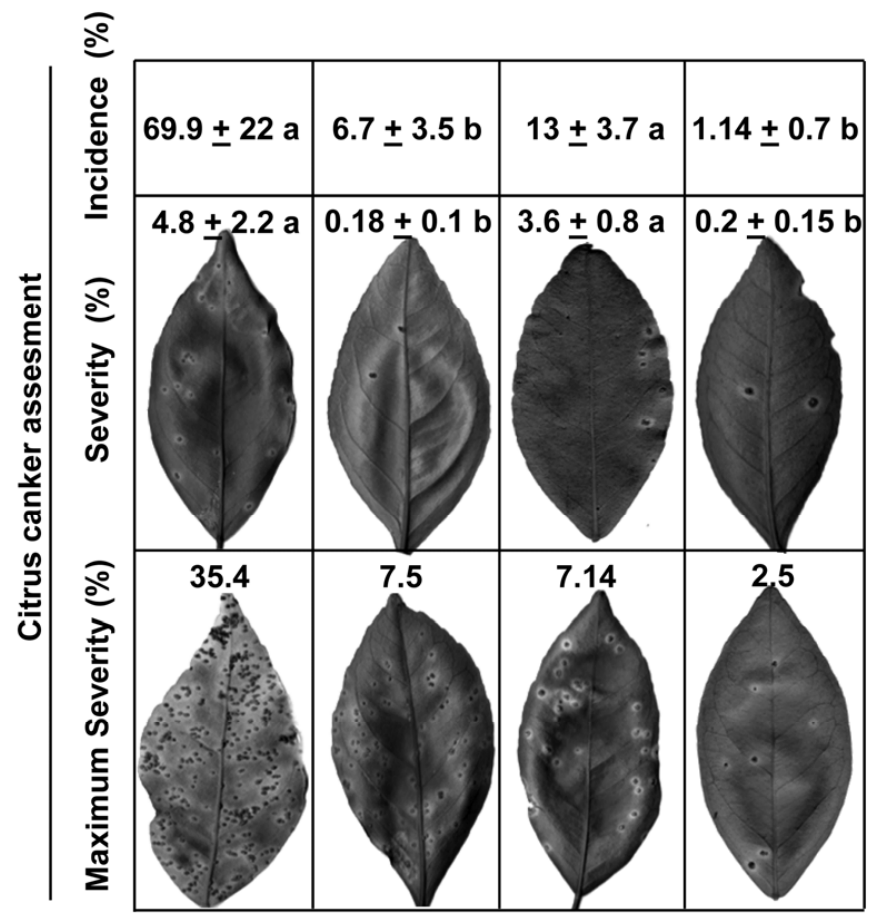

Fig. 1. Field assessment of citrus canker disease on randomly selected shoots of mandarin tree canopy. A, Phenological stages recorded in new shoots of the mandarin branches according to the Biologische Bundesanstalt, Bundessortenamt and Chemical industry $(\mathrm{BBCH})$ scale for citrus. $\mathbf{B}$, Incidence and severity of citrus canker disease. Incidence was quantified as the proportion of symptomatic leaves over total leaves examined in December of each year. Citrus canker severity was evaluated at the same time in the five most infected leaves of the shoots. Symptoms were recorded by digital photography and images are representative of the average found for each assessed parameter. Values are expressed as means \pm standard deviations. Means followed by different letters in the same line and year of evaluation differ significantly (Student's $t$ test, $P<0.05$ ). A completely random experimental design with single-tree plots and eight replications per cultivar was used.
Pathogenicity assays were performed under controlled growth conditions to determine whether the inoculation method affects differential citrus canker susceptibility between these mandarin cultivars. One leaf per shoot of 'Clemenules' and 'Okitsu' was inoculated with $X$. citri at 15, 18, 22, 25, and 27 days after the growth flush started. Bacterial inoculum was prepared at concentrations of $10^{3}$ and $10^{7} \mathrm{CFU} / \mathrm{ml}$ for infiltration and spraying, respectively. Canker lesions were quantified at 30 dpi. Comparison of canker severity, measured as number of cankers per area (in square centimeters), revealed no significant difference between 'Clemenules' and 'Okitsu' following inoculation via pressure infiltration (Fig. 2A). On both cultivars, the maximum number of cankerous lesions per square centimeter was observed in 15-day-old leaves (13 lesions $/ \mathrm{cm}^{2}$ on average), decreasing with the age of the leaf until reaching 6 lesions $/ \mathrm{cm}^{2}$ in 27-day-old leaves (Fig. 2A). However, a significant reduction in canker severity was observed in 'Okitsu' compared with 'Clemenules' when the bacteria were sprayed onto the leaves (Fig. 2B). These findings point to a substantial role for the leaf surface as a barrier against infection in 'Okitsu', particularly when leaves are inoculated at earlier stages. These results suggest that this barrier develops more quickly in 'Okitsu', in agreement with the more rapid phenological development found in this cultivar in the field, compared with 'Clemenules'.

To assess the bacterial growth kinetics during the maximum susceptibility period of both mandarin cultivars, 18-day-old leaves

A
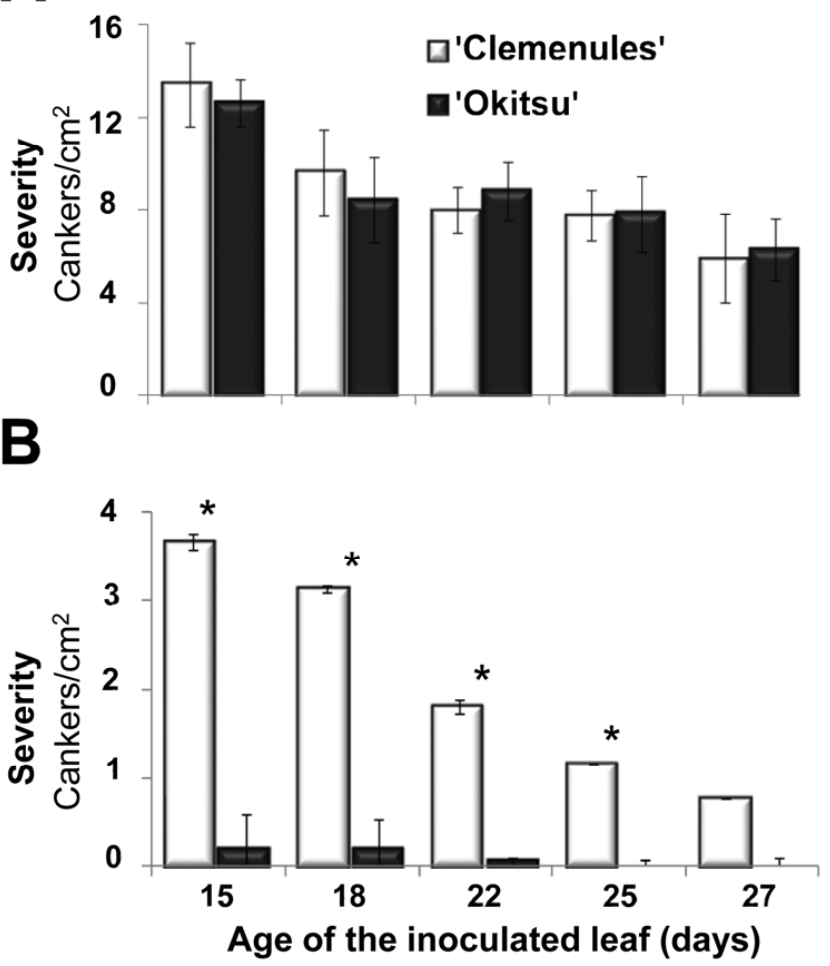

Fig. 2. Pathogenicity tests of Xanthomonas citri subsp. citri (X. citri) on mandarin leaves under controlled growth conditions. Mandarin leaves of different ages were inoculated with $X$. citri. Bacterial suspensions were prepared in $10 \mathrm{mM} \mathrm{MgCl} 2$ solution and inoculated onto leaf surfaces using two inoculation methods: $\mathbf{A}$, pressure infiltration or $\mathbf{B}$, spraying, respectively. Values are expressed as means \pm standard deviations. The data set marked with an asterisk is significantly different between both cultivars as assessed by the Student's $t$ test, $P<0.05$. All plant inoculations involved a minimum of two shoots from each plant and four plants for each cultivar and method of inoculation tested. Disease progression was monitored phenotypically in three separate biological assays and cankers per square centimeter were quantified 30 days postinoculation using Image $\mathrm{J}$ software (v 1.41; National Institutes of Health, Bethesda, MD). 
of 'Clemenules' and 'Okitsu' were inoculated with bacterial suspensions of $X$. citri by pressure infiltration or spraying, as described previously. In leaves subjected to pressure infiltration, the $X$. citri population gradually increased after the first day postinoculation in both mandarin cultivars, growing more than five orders of magnitude over the 2-week monitoring period (Fig. $3 \mathrm{~A})$. These results are consistent with the canker symptoms developed by $X$. citri on 'Clemenules' and 'Okitsu' inoculated by this method (Fig. 3A). However, significant differences in the bacterial growth patterns were found between the mandarin cultivars when the bacteria were inoculated by spraying. In 'Clemenules', the $X$. citri population increased by more than three orders of magnitude over the 2-week monitoring period. By contrast, the population of $X$. citri began to decline in 'Okitsu' $3 \mathrm{dpi}$, and no bacteria could be recovered after 2 weeks (Fig. 3B). Canker lesions were clearly observed in 'Clemenules', whereas almost none were observed in 'Okitsu' at 20 dpi (Fig. 3B).

$X$. citri cannot form a biofilm on 'Okitsu' leaf surface during the susceptibility period. Pathogen entry into the host tissue is a critical step in the establishment of the infection. Previously, bacteria persisted as epiphytes on the surface of healthy plants before starting the endophytic colonization process leading to disease (4). Biofilm formation is necessary for both epiphytic fitness and canker development by $X$. citri $(29,33)$.

The results described above suggest that differences in the properties of the leaf surface of 'Okitsu' and 'Clemenules' may contribute to the observed differences in their susceptibility to $X$. citri. These considerations prompted a comparative study of attachment, biofilm formation, and epiphytic fitness of $X$. citri on the leaf surface of the two cultivars. To investigate bacterial epiphytic fitness, leaf disks from 18-day-old 'Clemenules' and 'Okitsu' shoots were incubated with $X$. citri strain at $28^{\circ} \mathrm{C}$, as previously described (33). Bacterial attachment was observed by crystal violet staining after 1,5 , and $24 \mathrm{~h}$ of incubation. No significant differences were observed between the mandarin cultivars at the beginning of the plant-pathogen interaction ( 1 to $5 \mathrm{~h}$ ). However, attachment of $X$. citri increased significantly in 'Clemenules' after $24 \mathrm{~h}$ of incubation, particularly at plant cell junctions and around the guard cells forming stomatal pores, which represent an important entry route for X. citri (Fig. 4A).

As mentioned above, the presence of plant-associated bacterial biofilms is correlated with $X$. citri pathogenicity $(29,33)$. To assess biofilm development in both mandarin cultivars, 18-dayold 'Clemenules' and 'Okitsu' leaves were inoculated by spraying using $X$. citri-GFP and bacterial growth was monitored by fluorescent and confocal microscopy over a 10-day period. No significant differences were observed between the cultivars until 3 dpi (data not shown). However, the epiphytic population of $X$. citri in 'Clemenules' remarkably increased after 5 dpi throughout the monitoring period (Fig. 4B). We used confocal microscopy to study the structure of the bacterial aggregates formed during canker development. In 'Clemenules', the ZX axis-projected images showed the formation of compact microcolonies with a threedimensional structure (Fig. 4C). Conversely, the X. citri-GFP epiphytic population remained stable in 'Okitsu' and failed to form microcolonies or complex structures after 7 dpi (Fig. 4B and C).

Taken together, these results suggest that differences in leaf surface properties influence bacterial epiphytic fitness, attachment, and biofilm formation. Specifically, the leaf surface of 'Okitsu' appears to interfere with bacterial factors that are key for $X$. citri colonization and development of the disease.

'Okitsu' primary defenses also protect the plant from entry of the avirulent $X$. fuscans subsp. aurantifolii strain C. $X$. aurantifolii $\mathrm{C}$ elicits a hypersensitive response (HR) associated with cell death of infected tissue in all Citrus spp. except for $C$. aurantifolia leaves (11). This defense response is associated with the perception and recognition of the pathogen through a tight attachment to host mesophyll cells (9). To investigate further the role of the leaf surface in host defense against bacterial entry into citrus leaves, we performed pathogenicity tests with $X$. aurantifolii $\mathrm{C}$ in both 'Okitsu' and 'Clemenules' mandarin. Eighteenday-old leaves of 'Okitsu' and 'Clemenules' were inoculated with bacterial suspensions of $g f p$-tagged $X$. aurantifolii $\mathrm{C}$ (X. aurantifolii C-GFP), using both pressure infiltration and spraying. Upon infection by pressure infiltration, a typical HR was observed in both mandarin cultivars, clearly shown by total necrosis of the infiltrated area and the lack of $g f p$-tagged bacteria (Fig. 5A). On the other hand, discrete HR lesions were observed in 'Clemenules' at 15 days after spraying inoculation, whereas no lesions were detected in 'Okitsu' during the monitored period (Fig. 5B). A parallel experiment with the $X$. citri-GFP strain was used as control. Seven days after pressure infiltration, widespread GFP fluorescence was observed in both cultivars (Fig. 5A). However, 15 days after spraying, lesion development and GFP fluorescence were only observed in 'Clemenules' (Fig. 5B), as expected from previously described findings. Taken together, these results suggest that primary defenses of 'Okitsu' act as a barrier against the entry of citrus bacterial pathogens; thus, resistance is achieved without the requirement of the programmed host cell death response.

\section{DISCUSSION}

Citrus canker has been an endemic disease in Argentina since 2002. The replacement of citrus cultivars in current cultivation with those having full or partial resistance represents a sustainable strategy to manage the disease (39). However, characterization of citrus resistance to $X$. citri has only recently begun and is not completely understood $(10,12,15,23,24,26,41)$. In this work, we have revealed some of the factors that contribute to the enhanced resistance to citrus canker disease of 'Okitsu' mandarin under both field and controlled-growth conditions.

Field evaluations showed that 'Okitsu' has significantly lower disease incidence and severity than 'Clemenules'; these differ-
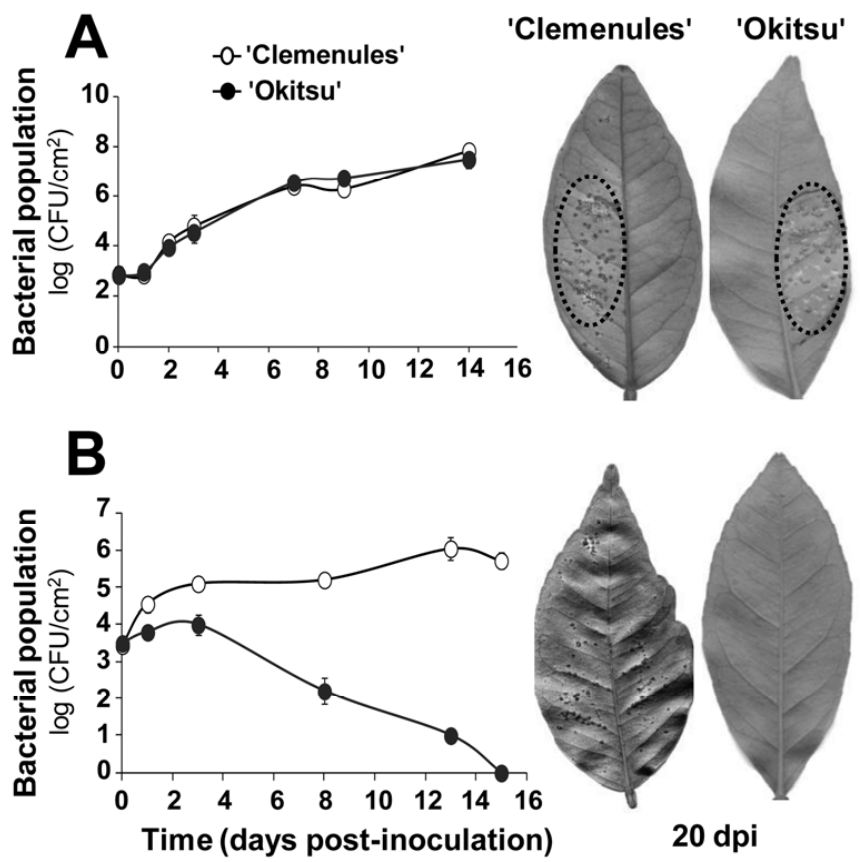

Fig. 3. Bacterial population growth in mandarin cultivars during the period of maximum citrus canker susceptibility. In planta growth of Xanthomonas citri subsp. citri on 18-day-old mandarin leaves and symptom development induced by bacteria inoculated by $\mathbf{A}$, pressure infiltration or $\mathbf{B}$, spraying. Values are expressed as means \pm standard deviations of three independent biological replicates, each consisting of three separate measurements of bacterial density from each cultivar. Dotted lines show the infiltrated area; $\mathrm{dpi}=$ days postinoculation 
$1 \mathrm{~h}$

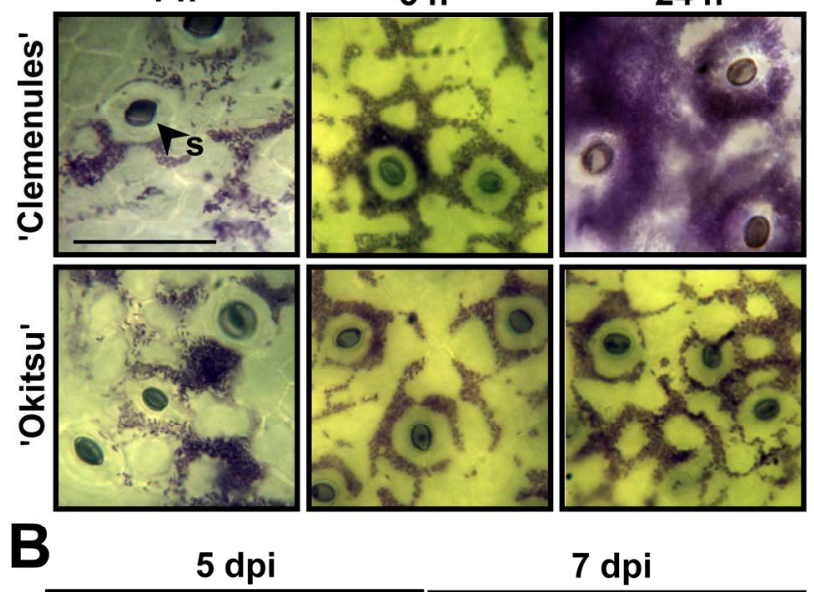

B

$5 \mathrm{~h}$
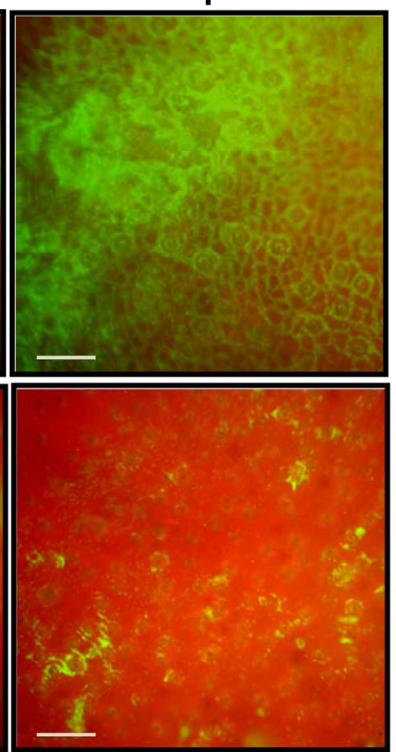

\section{C}
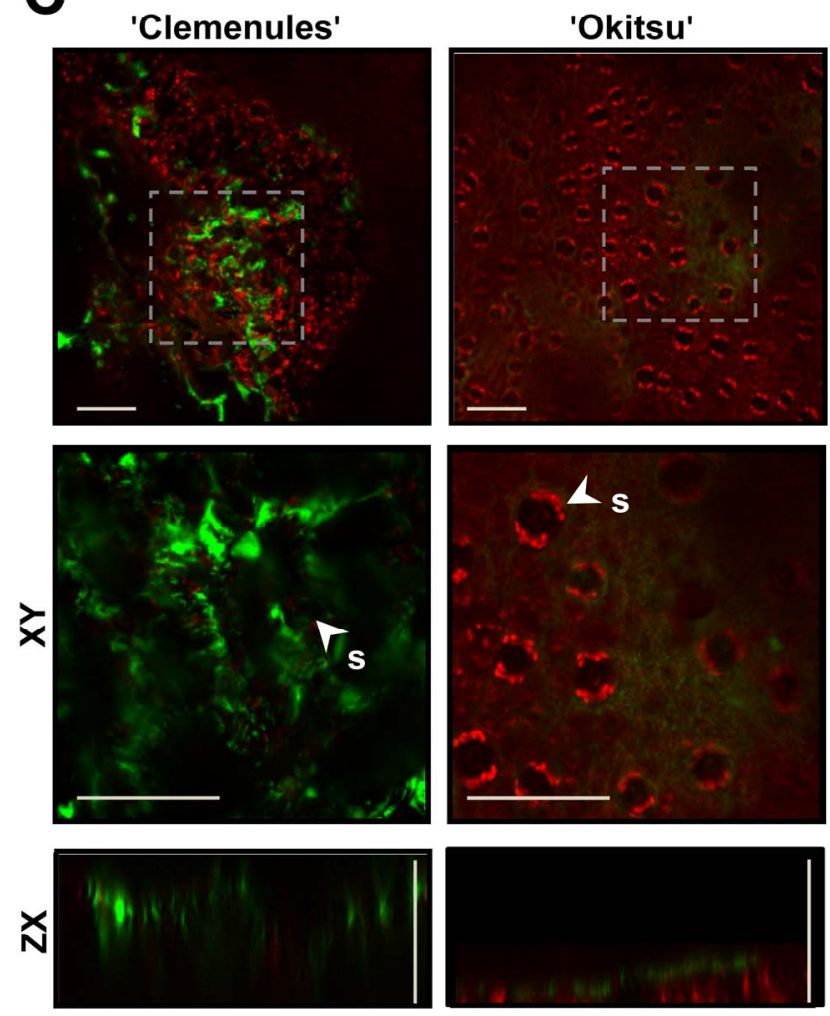

7 dpi

Fig. 4. 'Okitsu' leaf surface influences epiphytic fitness and biofilm formation of Xanthomonas citri subsp. citri (X. citri). A, Bacterial adhesion of X. citri on abaxial surfaces of 18-day-old leaves assessed by the use of crystal violet stain at 1,5 , and $24 \mathrm{~h}$ of incubation. Stained cells attached to the leaf surface were analyzed microscopically. B, Epiphytic growth and biofilm formation of green fluorescent protein ( $g f p)$-tagged X. citri strain (X. citri-GFP) sprayed on 18-day-old mandarin leaves monitored with a fluorescence microscope and $\mathbf{C}$, inverted confocal laser-scanning microscope. Sections from the upper panels are magnified in the lower panels. Red indicates chlorophyll autofluorescence and green indicates gfp-tagged bacteria. XY and XZ are the XY and XZ axis projected images, respectively. Scale bars $=50 \mu \mathrm{m}, \mathrm{s}=$ stomata, and dpi $=$ days postinoculation. The experiment was repeated on at least three different plants for each cultivar, and three leaves per plant were examined.

ences are associated with a more rapid transit between $\mathrm{BBCH} 15$ and $\mathrm{BBCH} 19$ stages, the period of optimal susceptibility to $X$. citri infection. These differences in disease incidence were also observed under controlled growth conditions, although exclusively when the leaves were inoculated by spraying, a noninvasive method. This result indicates that the resistance to canker disease depends on the integrity of a leaf surface barrier, which is most likely associated with the faster phenological development of 'Okitsu' shoots.

Several reports have shown that field canker resistance of other citrus species, cultivars, or related genera, including 'Dalan Dan' (a cultivar similar to $C$. paradisi), 'Lakeland' limequat ( $C$. aurantifolia $\times F$. japonica), calamondin $(C$. mitis), C. ichangensis, and $C$. junos, may be broken down when invasive inoculation methods are used $(12,18,19,39)$. Pressure infiltration may mechanically destroy and overcome the primary physical barriers in plant defense, such as the cuticle or cell wall. Alternatively, the spraying method provides conditions that may resemble the natural infection processes of $X$. citri through stomata, which is initiated with bacterial attachment to the plant surface and subsequent bio- film formation (33). In susceptible 'Clemenules', X. citri colonizes the leaf surface and subsequently forms microcolonies, particularly on the epidermal cell junctions and around stomata, which evolve into mature biofilms and, finally, develop canker disease. In contrast, a clear reduction in the number of attached bacteria and biofilm formation was observed on 'Okitsu' leaves.

These results suggest that some specific characteristics of the 'Okitsu' leaf surface, associated with the phenological stage, are involved in resistance to $X$. citri. The first physical layer of the leaf surface that can protect plants against pathogen infection is the cuticle, which is composed of cutin, a lipid-derived polyester, and cuticular waxes (3). It has been shown that the thickness and composition of this hydrophobic extracellular matrix can influence bacterial colonization of the leaf $(6,30,42)$. Thick, waxy cuticles have been shown to interfere with epiphytic bacterial colonization, inhibiting the wetting of the leaf surface and limiting solubilization and diffusion of nutrients from the leaf $(28,42)$. The cuticle develops rapidly during the leaf expansion process in Citrus spp. and the last stages of leaf expansion (i.e., two-thirds to full expansion) are coincident with a rapid development of this 


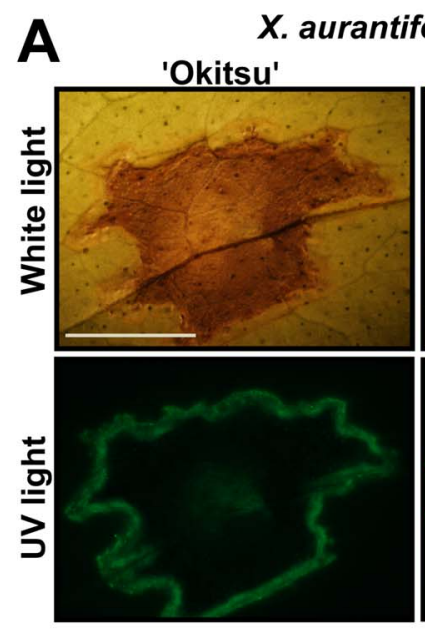

B

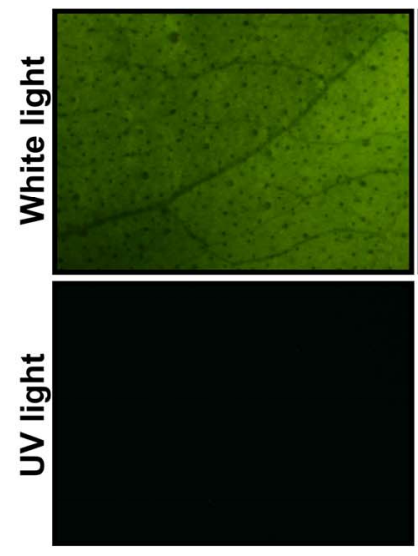

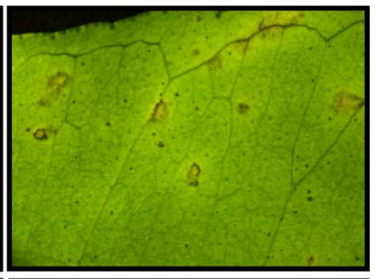

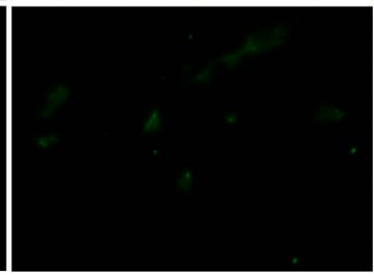

X. citri-GFP

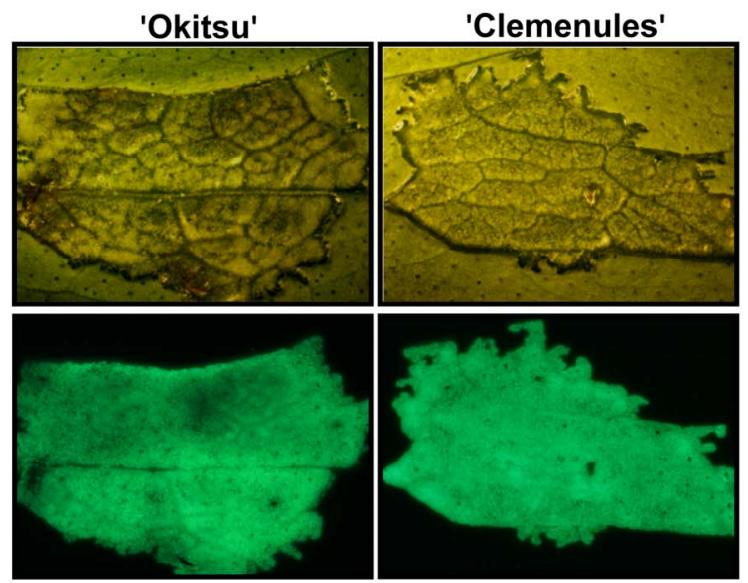

$7 \mathrm{dpi}$
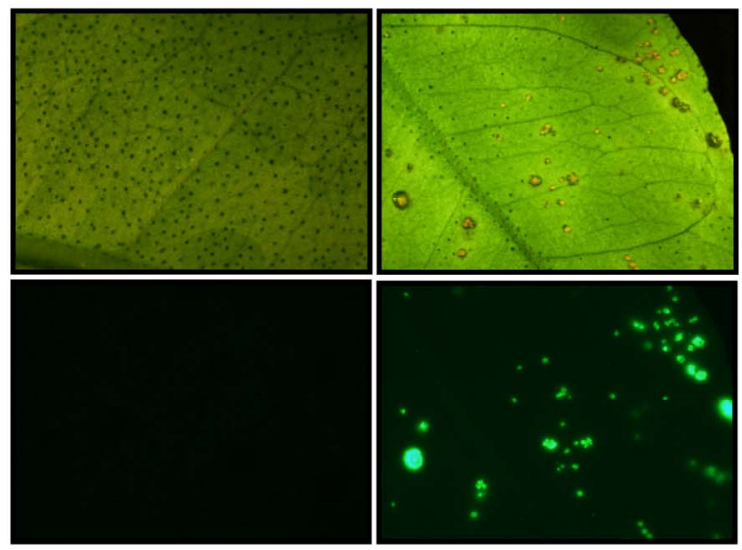

$15 \mathrm{dpi}$

Fig. 5. 'Okitsu' leaf surface influences entry of Xanthomonas spp. into leaves. Macroscopic symptoms on 18-day-old mandarin leaves 7 and 15 days postinoculation (dpi) with the green fluorescent protein ( $g f p$ )-tagged strains Xanthomonas fuscans subsp. aurantifolii C (X. aurantifolii C-GFP) and X. citri subsp. citri (X. citri-GFP). Bacterial suspensions were prepared in $10 \mathrm{mM} \mathrm{MgCl} 2$ solution and inoculated onto leaves surfaces using two inoculation methods: A, pressure infiltration and B, spraying. Leaves were photographed under white and UV light $(520 \mathrm{~nm})$, respectively. The experiment was repeated on at least three different plants for each cultivar with similar results. Scale bar $=10 \mathrm{~mm}$.

protective barrier (22). Consequently, the faster phenological development during the citrus canker susceptibility period of 'Okitsu' leaves may be associated with a rapid cuticle thickening. Furthermore, a thicker cuticle may prevent bacterial entry through stomata in 'Okitsu' because the cuticle layer forms a cuticular hood around the guard cells, creating an antechamber over the actual stomatal pore (22).

The number and anatomy of stomata have been suggested to contribute to the differential response to $X$. citri infection between a resistant kumquat genotype and a susceptible orange genotype (41). However, Graham et al. (22) could not associate the resistance to citrus canker with the area of opening and density of stomata among seven different Citrus spp. Further studies should advance our understanding of the role of the citrus cuticle in the defense response to Xanthomonas infection. Moreover, the finding that 'Okitsu' leaves have a shorter susceptibility period to $X$. citri should result in a optimization of copper bactericide applications, thus contributing to an integrated management of the disease.

\section{ACKNOWLEDGMENTS}

This work was principally supported by the Agencia Nacional de Promoción Científica y Tecnológica PICT-2011-1833 to M. R. Marano and by a grant from the Florida Citrus Research and Development
Foundation to F. G. Gmitter, Jr. and M. R. Marano. M. A. Chiesa, A. A. Vojnov, A. P. Castagnaro, and M. R. Marano are Career Investigators of CONICET. We thank R. Vena for his technical assistance with the confocal microscopy and J. M. Dow and G. Gudesblat for critical review of the manuscript.

\section{LITERATURE CITED}

1. Agustí, M., Zaragoza, S., Bleiholder, H., Buhr, L., Hack, H., Klose, R., and Staub, R. 1997. Adaptation de l'échelle $\mathrm{BBCH}$ à la description des stades phénologiques des agrumes du genre Citrus. Fruits 52:287-295.

2. Altube, H. A., Santinoni, L. A., and Alem, J. H. 2007. Introducción a la Fruticultura. Pages 3-38 in: Árboles Frutales: Ecofisiología, Cultivo y Aprovechamiento. G. O. Sozzi, ed. FAUBA, Buenos Aires, Argentina.

3. Beattie, G. A. 2002. Leaf surface waxes and the process of leaf colonization by microorganisms. Pages 3-26 in: Phyllosphere Microbiology. S. E. Lindow, E. I. Hecht-Poinar, and V. J. Elliott, eds. American Phytopathological Society Press, St. Paul, MN.

4. Beattie, G. A., and Lindow, S. E. 1999. Bacterial colonization of leaves: a spectrum of strategies. Phytopathology 89:353-359.

5. Belasque, J., Jr., Bassanezi, R. B., Sposito, M. B., Ribeiro, L. M., Jesus, W. C., Jr., and Amorim, L. 2005. Escalas diagramaticas para avaliação da severidade do cancro cítrico. Fitopatol. Bras. 30:387-393.

6. Bessire, M., Chassot, C., Jacquat, A.-C., Humphry, M., Borel, S., MacDonald-Comber Petétot, J., Métraux, J.-P., and Nawrath, C. 2007. A permeable cuticle in Arabidopsis leads to a strong resistance to Botrytis cinerea. EMBO J. 26:2158-2168.

7. Bock, C. H., Parker, P. E., and Gottwald, T. R. 2005. Effect of simulated 
wind-driven rain on duration and distance of dispersal of Xanthomonas axonopodis pv. citri from canker-infected citrus trees. Plant Dis. 89:71-80.

8. Canteros, B. I. 2004. Management of Citrus canker in Argentina. A review. Abstr. No. 90. Xth Int. Citrus Congr. Agadir, Morocco.

9. Cernadas, R. A., Camillo, L. R., and Benedetti, C. E. 2008. Transcriptional analysis of the sweet orange interaction with the citrus canker pathogens Xanthomonas axonopodis pv. citri and Xanthomonas axonopodis pv. aurantifolii. Mol. Plant Pathol. 9:609-631.

10. Chen, P.-S., Wang, L.-Y., Chen, Y.-J., Tzeng, K.-C., Chang, S.-C., Chung, K.-R., and Lee, M.-H. 2012. Understanding cellular defence in kumquat and calamondin to citrus canker caused by Xanthomonas citri subsp. citri. Physiol. Mol. Plant Pathol. 79:1-12.

11. Chiesa, M. A., Siciliano, M. F., Ornella, L., Roeschlin, R. A., Favaro, M. A., Delgado, N. P., Sendín, L. N., Orce, I. G., Ploper, L. D., Vojnov, A. A., Vacas, J. G., Filippone, M. P., Castagnaro, A. P., and Marano, M. R. 2013. Characterization of a variant of Xanthomonas citri subsp. citri that triggers a host-specific defense response. Phytopathology 103:555-564.

12. Deng, Z. N., Xu, L., Li, D. Z., Long, G. Y., Liu, L. P., Fang, F., and Shu, G. P. 2010. Screening citrus genotypes for resistance to canker disease (Xanthomonas axonopodis pv. citri). Plant Breed. 129:341-345.

13. do Amaral, A. M., Carvalho, S. A., Silva, L. F. C., and Machado, M. A. 2010. Reaction of genotypes of Citrus species and varieties to Xanthomonas citri subsp. citri under greenhouse conditions. J. Plant Pathol. 92:519-524.

14. do Amaral, A. M., Toledo, C. P., Baptista, J. C., and Machado, M. A. 2005. Transformation of Xanthomonas axonopodis pv. citri by electroporation. Fitopatol. Bras. 30:292-294.

15. Fu, X.-Z., Gong, X.-Q., Zhang, Y.-X., Wang, Y., and Liu, J.-H. 2012. Different transcriptional response to Xanthomonas citri subsp. citri between kumquat and sweet orange with contrasting canker tolerance. PLoS One 7:e41790. doi:10.1371/journal.pone.0041790

16. García, M. S., Leva, P. E., Zbrun, M. E., Veles, M. A., Gandolfo, J. A., and Valtorta, S. E. 2002. Tendencias de índices meteorológicos y biometeorológicos. Rev. FAVE Cienc. Agrar. 1:27-36.

17. Gariglio, N. F., Mendow, M., Weber, M. E., Favaro, M. A., GonzálezRossia, D. E., and Pilatti, R. A. 2009. Phenology and reproductive traits of peaches and nectarines in Central-East Argentina. Sci. Agric. 66:757763.

18. Gochez, A. M., and Canteros, B. I. 2008. Resistance to citrus canker caused by Xanthomonas citri pv. citri in an accession of Citrus sp. similar to grapefruit. Plant Dis. 92:652.

19. Gottwald, T. R., Graham, J. H., Civerolo, E. L., Barrett, H. C., and Hearn, C. J. 1993. Differential host range reaction of citrus and citrus relatives to citrus canker and citrus bacterial spot determined by leaf mesophyll susceptibility. Plant Dis. 77:1004-1007.

20. Gottwald, T. R., Graham, J. H., and Schubert, T. S. 2002. Citrus canker: the pathogen and its impact. Plant Health Progress. Online publication. doi:10.1094/PHP-2002-0812-01-RV

21. Graham, J. H., Gottwald, T. R., Cubero, J., and Achor, D. S. 2004. Xanthomonas axonopodis pv. citri: factors affecting successful eradication of citrus canker. Mol. Plant Pathol. 1:1-15.

22. Graham, J. H., Gottwald, T. R., Riley T. D., and Achor, D. S. 1992. Penetration through leaf stomata and growth of strains of Xanthomonas campestris in citrus cultivars varying in susceptibility to bacterial diseases. Phytopathology 82:1319-1325.

23. Khalaf, A. A., Gmitter, F. G., Jr., Conesa, A., Dopazo, J., and Moore, G. A. 2011. Fortunella margarita transcriptional reprogramming triggered by Xanthomonas citri subsp. citri. BMC Plant Biol. 11:159. Online publication. doi:10.1186/1471-2229-11-159

24. Khalaf, A. A., Moore, G. A., Jones, J. B., and Gmitter, F. G., Jr. 2007. New insights into the resistance of Nagami kumquat to canker disease.
Physiol. Mol. Plant Pathol. 71:240-250.

25. Köppen, W. 1936. Das geographische System der Klimate. Pages 1-44 in: Handbuch der Klimatologie. W. Köppen, and R. Geiger, eds. Verlag von Gebrüder Borntraeger, Berlin

26. Lee, I. J., Kim, K. W., Hyun, J. W., Lee, Y. H., and Park, E. W. 2009. Comparative ultrastructure of nonwounded Mexican Lime and Yuzu leaves infected with the citrus canker bacterium Xanthomonas citri pv. citri. Microsc. Res. Techniq. 72:507-516.

27. Leite, R. P., Jr., Mohan, S. K., Pereira, A. L. G., and Campacci, C. A. 1987. Integrated control of citrus canker: effect of genetic resistance and application of bactericides. Fitopatol. Bras. 12:257-263.

28. Lindow, S. E., and Brandl, M. T. 2003. Microbiology of the phyllosphere. Appl. Environ. Microbiol. 69:1875-1883.

29. Malamud, F., Torres, P. S., Roeschlin, R., Rigano, L. A., Enrique, R., Bonomi, H. R., Castagnaro, A. P., Marano, M. R., and Vojnov, A. A. 2011. The Xanthomonas axonopodis pv. citri flagellum is required for mature biofilm and canker development. Microbiology 157:819-829.

30. Marcell, L. M., and Beattie, G. A. 2002. Effect of leaf surface waxes on leaf colonization by Pantoea agglomerans and Clavibacter michiganensis. Mol. Plant-Microbe Interact. 15:1236-1244.

31. Mesejo, C., Martínez-Fuentes, A., Reig, C., and Agustí, M. 2007. The effective pollination period in 'Clemenules' mandarin, 'Owari' Satsuma mandarin and 'Valencia' sweet orange. Plant Sci. 173:223-230.

32. Palou, L., Jacas, J. A., Marcilla, A., Alonso, M., and del Río, M. A. 2008. Physico-chemical and sensory quality of 'Clemenules' mandarins and survival of the Mediterranean fruit fly as affected by complementary cold and carbon dioxide quarantine treatments. Postharvest Biol. Technol. 48:443-450.

33. Rigano, L. A., Siciliano, F., Enrique, R., Sendin, L., Filippone, P., Torres, P. S., Questa, J., Dow, J. M., Castagnaro, A. P., Vojnov, A. A., and Marano, M. R. 2007. Biofilm formation, epiphytic fitness, and canker development in Xanthomonas axonopodis pv. citri. Mol. Plant-Microbe. Interact. 20:1222-1230.

34. Schubert, T. S., Rizvi, S. A., Sun, X. A., Gottwald, T. R., Graham, J. H., and Dixon, W. N. 2001. Meeting the challenge of eradicating citrus canker in Florida-again. Plant Dis. 85:340-356.

35. Shiotani, H., Uematsu, H., Tsukamoto, T., Shimizu, Y., Ueda, K., Mizuno, A., and Sato, S. 2009. Survival and dispersal of Xanthomonas axonopodis pv. citri from infected Satsuma mandarin fruit. Crop Prot. 28:19-23.

36. Shiotani, H. Y. T., Yamamoto, M., and Matsumoto, R. 2008. Susceptibility to citrus canker caused by Xanthomonas axonopodis pv. citri depends on the nuclear genome of the host plant. J. Gen. Plant Pathol. 74:133-137.

37. Stall, R. E., Marcó, G. M., and Canteros de Echenique, B. I. 1982. Importance of mesophyll in mature-leaf resistance to cancrosis of citrus. Phytopathology 72:1097-1100.

38. Stover, E., Castle, W., and Chao, C. C. 2005. Trends in US sweet orange, grapefruit, and mandarin-type cultivars. HortTechnology 15:501-506.

39. Viloria, Z., Drouillard, D. L., Graham, J. H., and Grosser, J. W. 2004. Screening triploid hybrids of 'Lakeland' limequat for resistance to citrus canker. Plant Dis. 88:1056-1060.

40. Vojnov, A. A., do Amaral, A. M., Dow, J. M., Castagnaro, A. P., and Marano, M. R. 2010. Bacteria causing important diseases of citrus utilize distinct modes of pathogenesis to attack a common host. Appl. Microbiol. Biotechnol. 87:467-477.

41. Wang, Y., Fua, X. Z., Liua, J. H., and Hong, N. 2011. Differential structure and physiological response to canker challenge between 'Meiwa' kumquat and 'Newhall' navel orange with contrasting resistance. Sci. Hortic. 128:115-123.

42. Whipps, J. M., Hand, P., Pink, D., and Bending, G. D. 2008. Phyllosphere microbiology with special reference to diversity and plant genotype. J. Appl. Microbiol. 105:1744-1755. 